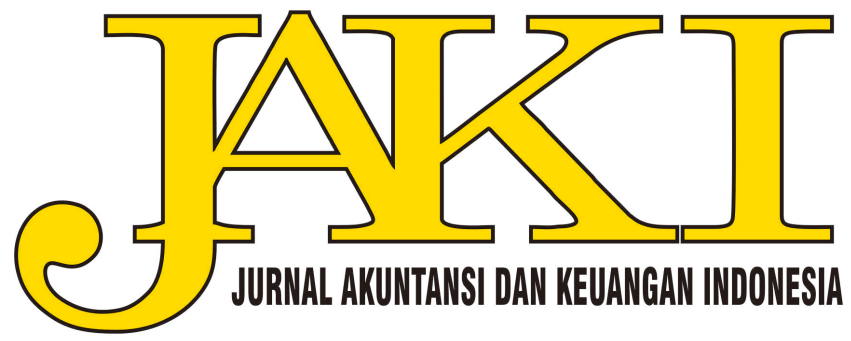

Volume 17

Issue 1 Volume 17, Issue 1, 2020

Article 2

$6-30-2020$

\title{
THE EFFECT OF CONCENTRATED OWNERSHIP ON BANK PROFITABILITY IN INDONESIA
}

\author{
Michelle Priscilla Amanda \\ Universitas Prasetiya Mulya \\ Serafina Lam \\ Universitas Prasetiya Mulya \\ Rinaningsih . \\ Universitas Prasetiya Mulya \\ Yang Elvi Adelina \\ Universitas Prasetiya Mulya
}

Follow this and additional works at: https://scholarhub.ui.ac.id/jaki

Part of the Accounting Commons, Corporate Finance Commons, Finance and Financial Management Commons, and the Taxation Commons

\section{Recommended Citation}

Amanda, Michelle Priscilla; Lam, Serafina; ., Rinaningsih; and Adelina, Yang Elvi (2020) "THE EFFECT OF CONCENTRATED OWNERSHIP ON BANK PROFITABILITY IN INDONESIA," Jurnal Akuntansi dan Keuangan Indonesia: Vol. 17: Iss. 1, Article 2.

DOI: 10.21002/jaki.2020.02

Available at: https://scholarhub.ui.ac.id/jaki/vol17/iss1/2

This Article is brought to you for free and open access by the Faculty of Economics \& Business at UI Scholars Hub. It has been accepted for inclusion in Jurnal Akuntansi dan Keuangan Indonesia by an authorized editor of UI Scholars Hub. 
Jurnal Akuntansi dan Keuangan Indonesia

Volume 17 Nomor 1, Juni 2020

\title{
THE EFFECT OF CONCENTRATED OWNERSHIP ON BANK PROFITABILITY IN INDONESIA
}

\author{
Michelle Priscilla Amanda \\ Accounting Study Program, Universitas Prasetiya Mulya \\ michelle.amanda@student.pmsbe.ac.id \\ Serafina Lam \\ Accounting Study Program, Universitas Prasetiya Mulya \\ serafina.lam@student.pmsbe.ac.id \\ Rinaningsih \\ Accounting Study Program, Universitas Prasetiya Mulya \\ rinaningsih@prasetiyamulya.ac.id \\ Yang Elvi Adelina \\ Accounting Study Program, Universitas Prasetiya Mulya \\ yang.adelina@prasetiyamulya.ac.id
}

\begin{abstract}
This paper examines the association between concentrated ownership and the profitability of banks in Indonesia during the period from 2012 to 2018 with a total sample of 93 banks or 651 observations. This study applies the Random Effect regression method, and reveals a non-significant association between concentrated ownership and bank profitability as measured by ROA and ROE. It indicates that a majority of shareholders tend to use their power to exploit minority shareholders, which can also strengthen the monitoring effect. However, the regression also indicates that there is a significant nonlinear relationship between concentrated ownership and profitability when measured by ROE. There is a mixed-effect between concentrated ownership and profitability in the case of Indonesian banks. Moreover, a regression is also utilized with dummy variables of concentrated ownership (FIN and IND) to assess the difference between non-financial institution ownership and financial institution ownership. The results show no significant difference in cases. This can be caused by institutional ownership (financial institutions), which only acts as a short-term trader that emphasizes short-term profits. Therefore, its existence as a shareholder is not any different to the presence of non-financial institution ownership. The findings of this study show that the application of POJK No. 56/POJK.03/2016 regarding Share Ownership of Commercial Banks which regulates the maximum limit of concentrated ownership in banks may not work effectively in strengthening bank performance.
\end{abstract}

Keywords: Concentrated ownership, banks, OJK regulations, bank performance, expropriation.

\begin{abstract}
Abstrak
Penelitian ini bertujuan untuk meneliti pengaruh kepemilikan terkonsentrasi terhadap profitabilitas bank di Indonesia pada periode tahun 2012 sampai dengan tahun 2018 dengan sampel sejumlah 93 bank atau 651 observasi. Pengujian dengan metode regresi Random Effect menunjukkan hubungan tidak signifikan antara kepemilikan terkonsentrasi dengan profitabilitas bank yang diukur dengan ROA dan ROE. Hal ini mengindikasikan bahwa pemegang saham mayoritas bukan hanya dapat memanfaatkan kekuasaan yang dimilikinya untuk mengekspropriasi pemegang saham minoritas, namun juga dapat memperkuat
\end{abstract}


pelaksanaan fungsi pengawasan. Selain itu, hasil regresi juga menunjukkan bahwa terdapat hubungan signifikan non-linear antara kepemilikan terkonsentrasi dan profitabilitas ketika diukur menggunakan ROE. Maka dari itu, pada kasus bank di Indonesia, terdapat mixed-effect terkait kepemilikan terkonsentrasi dan profitabilitas. Selanjutnya, regresi dengan menggunakan variable dummy dari kepemilikan terkonsentrasi (FIN dan IND) untuk melihat apakah ada perbedaan pada performa bank yang dikuasai oleh lembaga keuangan dan non-lembaga keuangan. Hasilnya menunjukan tidak adanya perbedaan signifikan. Hal ini dapat disebabkan ketika kepemilikan lembaga keuangan hanya bertindak sebagai investor jangka pendek atau short-term trader yang tujuannya adalah keuntungan jangka pendek. Sehingga kehadiran dari kepemilikan lembaga keuangan tersebut tidak berbeda dari kehadiran kepemilikan lembaga non-keuangan. Hasil dari penelitian ini menunjukkan bahwa penerapan POJK Nomor 56/POJK.03/2016 tentang Kepemilikan Saham Bank Umum, yang mengatur batasan maksimum kepemilikan terkonsentrasi pada perbankan, untuk membantu meningkatkan performa bank belum berjalan secara efektif.

Kata Kunci: Kepemilikanterkonsentrasi, bank, peraturan OJK, performa bank, ekspropriasi.

\section{INTRODUCTION}

Banks are one of the cornerstones that help drive the economy in today's emerging economies because they tend to finance their countries' economic growth through bank loans (Vo 2017). Banking is one of the most highly regulated industries because a crisis for banks will impact the overall economy of a country. Therefore, banks are required to have higher corporate governance compared to other industries (Bolton 2002).

Good corporate governance is needed for a more effective, objective, and transparent practice of the company's operations. This is important in order to maintain the alignment of the achievement of company goals and to avoid managerial behavior that can harm the company. Rationally, each person has the desire to benefit themselves. In the company context, shareholders have a desire to maximize the performance and value of a company, while managers have the desire to prioritize their own interests. Such a scheme is known as the agency problem (Jensen and Meckling 1976). When an agency problem occurs, the agency cost will increase because the management's actions are not in accordance with the wishes of the shareholders, and can certainly affect the company's performance or value. In Indonesia, a study conducted on the relationship between the application of corporate governance and the profitability of banks revealed an insignificant relationship (Putra et al. 2019). This is allegedly because the implementation of governance was still not optimal, as there were no clear consequences for governance non-compliance.

Corporate governance plays a large role in protecting investors because without it, investors cannot ensure that the funds they have invested in the company are well managed by managers (Shleifer and Vishny 1986). There are several corporate governance mechanisms to address agency problems, one of which is concentrated ownership, which is one of the important mechanisms to reduce agency problems ( $\mathrm{La}$ Porta et al. 1998). Under concentrated ownership, owners can directly influence management to protect their interests (Shleifer and Vishny 1986).

Concentrated ownership can overcome agency problems through monitoring effects. Some researchers believe that concentrated ownership can monitor manager behavior because ownership in a large percentage is considered to have strong influence and a better ability to conduct supervision (Shleifer and Vishny 1986). Thus, managers become more controlled in their behavior and cannot act to benefit themselves, thus reducing the prosperity of shareholders (Shleifer andVishny 1986).

On the contrary, the existence of concentrated ownership can also lead to another agency problem, namely an expropriation 
effect in which there is a tendency for majority shareholders to seize the rights of minority shareholders through the control they have (Faccio and Stolin 2006; Shleifer andVishny 1997).

According to La Porta et al. (2002), developing countries still lack investor protection and regulation of corporate governance compared to developed countries. A study by La Porta et al. (1999, 1997, 1998, 2002) recognized that there are differences in the legal systems of various countries; the level of investor protection was found to be higher in common law countries and weaker in civil law countries. Indonesia is a civil law country thus it has low investor protection. This affects how shareholders can easily take advantage of their control and allow the emergence of expropriation effects (La Porta et al. 2002).

The relationship between concentrated ownership and value, or performance, and the efficiency of the company is still under debate. Many previous studies have examined the relationship between concentrated ownership with performance on both non-financial companies and financial or banking companies (Alimehmeti and Paletta 2012; Bian and Deng 2017; Boussaada and Karmani 2015; Lee and Lee 2014; Ozili and Uadiale 2017; Saidi and AlShammari 2015; Surifah 2011; Yasser and Mamun 2017). However, the results of these studies are not consistent. Some results state that there is a positive association between concentrated ownership and bank profitability due to monitoring effects (Boussaada and Karmani 2015; Ozili and Uadiale 2017; Yasser and Mamun 2017). Other studies also state that the relationship between the two is negative because of the dominating effect of expropriation (Bian and Deng 2017; Lee and Lee 2014).

Some studies have also found that concentrated ownership and company performance have a non-linear relationship due to the mixed-effects between the monitoring and expropriation effects (Alimehmeti and Paletta 2012; Enqvist 2005). According to Alimehmeti and
Paletta (2012), the relationship between concentrated ownership and company performance is basically positive (monitoring effect dominates). However, when a crisis occurs, a negative association between concentrated ownership and performance arises due to the more dominant expropriation effect. Some studies actually state that concentrated ownership actually has no after effect on company performance (Demsetz and Lehn 1985: King and Santor 2007; Surifah 2011). Surifah (2011) stated that the percentage of concentrated ownership has no effect on profitability because concentrated ownership has existed for a long time and is not sensitive to changes in the percentage of ownership, thus it does not have an impact on the bank's profitability.

This is an interesting research topic for review because there are still inconsistencies within the results of previous studies. Indonesia was selected for observation for several reasons. First, the lack of shareholder protection in developing countries usually leads to high ownership concentration (La Porta et al. 1998). Secondly, Indonesia ranked first in terms of the country with the highest number of banks across South East Asia (Ananta 2019; Hariyanti 2018). In addition, the existence of regulations in Indonesia that regulate concentrated ownership for banks makes this topic even more pertinent. This latter aspect is regulated by the Peraturan Otoritas Jasa Keuangan (POJK) No. 56/ POJK.03/ 2016 regarding the Share Ownership of Commercial Banks in relation to the limitation of bank share ownership in Indonesia. Indonesia's banks are encouraged by the government to consolidate with the hope of strengthening the capital structure of the bank. In order to support Indonesia's bank consolidation, the government has issued regulations related to the limitation of bank share ownership in Indonesia. The basis for the establishment of this regulation by Bank Indonesia (BI) is the failure to regulate good governance in banks; thereby it became the main cause of the financial crisis in 1997, which indicated 
that concentrated ownership in banks was related to the implementation of banking governance. This is reflected in POJK No. 56/POJK.03/2016 regarding the Share Ownership of Commercial Banks, which explains that the basis for the founding of this regulation was in consideration of Indonesia's financial crisis in 1997. The crisis showed that ownership domination, especially concentrated ownership of a bank, is closely and negatively related to the implementation of good banking governance (OJK 2016). Many bank owners at the time were also company owners, so when a crisis occurred, the owner of the company took advantage of the bank they owned for the sake of their company (Surifah 2011). This expropriation act of concentrated shareholders eventually sacrificed the banks and the minority shareholders of these banks. Moreover, since the regulation of POJK No. 11/POJK.03/2016 stated that the minimum capital requirement of a bank only varies between $8 \%-14 \%$, then the remaining $86 \%-92 \%$ of the banks' capital is gained from its customers. This insinuates that the customers suffer more from expropriation. The researchers expect that this study will reveal a negative association between concentrated ownership of banking performance so that it can support the implementation of the limitation of concentrated ownership in Indonesian banks.

This study also examined how concentrated ownership limitation is applied by banks in Indonesia. According to the Indonesian Banking Statistics (OJK2018), the number of banks in Indonesia in 2018 amounted to 115 banks. This was not in line with the provision of regulators or the government, which can be seen from the government's efforts to continue bank consolidation in Indonesia so that the numbers are reduced. In addition, there is an important aspect to consider: since Indonesia as a developing country prioritizes bankoriented financing, BI wants bank ownership in Indonesia to be dispersed through bank consolidation. The aim is not to create dominance of share ownership in banks, so that it can later strengthen bank resilience through its capital structure (OJK 2016).

Thus, this research aims to contribute empirical evidence regarding the suitability of the implementation of regulations to strengthen capital structure through a dispersed ownership structure. If it is proven that concentrated ownership is negatively and significantly associated with the profitability of the company, then this will provide insight that banks can increase their incentives through dispersed ownership and thus improve profitability.

Reference to OJK regulations related to the limitation of share ownership in banks reveals that the classification of ownership limits is based on company categories. Bank and non-bank financial institutions have the largest maximum ownership limit of $40 \%$, while the non-financial institution ownership limit is $30 \%$, and $20 \%$ for individual ownership. Many hope that the composition of such bank ownership limits can strengthen the resilience of banks in facing economic developments. From the composition of ownership determined by the regulator, financial institutions appear to have the largest composition compared to non-financial institutions and individuals. In other words, financial institutions are trusted as owners who can manage the bank better than non-financial institutions and individuals can. This is also in line with the findings by Chan and Lakonishok (1995), where institutional ownership such as in financial institutions is more sophisticated than the ownership of other institutions. Within the ownership structure of a company, institutional ownership is one of the instruments of corporate governance (Wardhani 2007). Shleifer (1986) found a positive relationship between institutional ownership and company performance for reason, that institutional ownership can actively monitor the company (active monitoring), minimize agency problems, and prevent information asymmetry.

On the contrary, there is another study that does not find a significant relationship 
between institutional ownership and company performance such as demonstrated in Kuwait, because corporate governance has not received much attention there (Saidi and Al-Shammari 2015). David and Kochhar (1996) expressed a different view of passive monitoring. This view assumes that institutional ownership does not interfere in management and tends to involve shortterm traders to gain short-term profits. In such a case, a negative relationship between institutional ownership and company performance will occur. Elyasiani and Jia (2010) also found a negative relationship based on the exploitation view, in which institutional investors can side with management to exploit minority shareholders and reduce company performance in the interest of institutional ownership. Cornett et al. (2007) also support this argument, stating that some short-term institutional owners or traders mostly pay attention to the shortterm results rather than long-term development. Thus, they might try to gain self-advantages at the cost of other shareholders. Because there are still inconsistencies in the results of research between institutional ownership and company performance, this study serves as an interesting contribution to this field of research. It will also examine the application of regulations for the limiting ownership of financial institutions and non-financial institutions in Indonesian banks.

Similar to research conducted by La Porta et al. (1998), this study is also fixated on testing the effects of concentrated ownership on company performance. In addition, it also focuses on the existence of POJK No. 56/POJK.03/2016 regarding Share Ownership of Commercial Banks and the absence of previous studies that conducted difference testing on bank performance and bank concentrated ownership by financial institutions and non-banks. Therefore, the main contribution of this research is to analyze the suitability between OJK regulations and the actual condition of banks in Indonesia. The outcomes of this study revealed a negative significant relationship between concentrated ownership and the performance of banks in Indonesia. Concentrated ownership by non-financial institutions in banks also shows better performance compared to concentrated ownership by financial institutions.

This study is divided into several parts. The first part provides the introduction. The second part consists of the literature review and hypothesis development. The following third part provides the research method, and the fourth part discusses the results and discussion. The last and fifth part confers conclusions, implications, and limitations.

\section{LITERATURE REVIEW AND HYPOTHESIS DEVELOPMENT}

\section{Literature Review}

\section{Agency Theory}

According to the study of Jensen and Meckling (1976), agency relations represent a relationship between one or a group of people termed principals with another one or a group of people termed agents, in which the principal has the right to delegate agents of authority in making decisions to help realize their interests. In practice, agents do not always act in accordance with the principal's interests due to differences in interests between the two (Rankin et al. 2012).

Jensen and Meckling (1976) declared three categories of relationships that can cause agency problems. The first is the relationship between shareholders and management. This relationship explains the importance of the differences in interests (as a principal) with those in management (as an agent).

Subsequently, the second one is the relationship between the majority shareholders and minority shareholders. The agency problem in this relationship might arise when the majority of shareholders do things that can harm minority shareholders, 
such as seizing the rights of minority shareholders because the majority shareholders have more control over the company.

The third is the relationship between the company (internal) and stakeholders outside the company (external), such as creditors. An agency problem that might arise in this relationship occurs when the company (agent) ignores the rights of the creditor (principal).

Within the company, efforts are needed to avoid or resolve agency problems when such problems arise between two parties, such as monitoring. Monitoring action is applied to prevent agents from taking actions that are outside the company's interests for personal gain.

Specifically, in this study, agency problems could arise due to the existence of concentrated ownership. There are two cases regarding concentrated ownership and agency problems. The first one is the agency problem between majority shareholders and the manager, or is widely known as the monitoring effect. In this situation, the majority shareholders with concentrated ownership will likely monitor and control the manager to make sure that the decisions made are in the interest of the shareholders. The second one is the agency problem between the majority and minority shareholders, or otherwise recognized as the expropriation effect. In this case, the majority or controlling shareholders will act as the principals and utilize their power to seize the rights of minority shareholders who act as agents. This can be done by exploiting company resources and taking corporate actions for personal interests as opposed to the rights of minority shareholders.

There are also some existing literature regarding two topics that are important for ownership structure but yet to be examined in this research, thus serves as a limitation of this study. The first topic is the difference between ownership or cashflow rights and control/voting rights, which result in either an alignment or entrenchment effect. The second is the role of multiple large shareholders.
However, although these two topics are not examined in this study, their concepts will still be explained in this section. Initially, when the largest shareholders have greater ownership or cash flow rights, they may be able to reduce the agency cost due to the incentive and means to supervise the agent. Thus greater cash flow rights create more incentive for the shareholders to optimize the shareholders' wealth, hence raising the profitability of a firm (Claessens et al. 2002; Utama et al. 2017). This is called the alignment effect. As the divergence between cash flow rights and control rights broaden, the controlling shareholders tend to expropriate the rights of the minority shareholders. When the controlling shareholders expropriate the company assets for their own private benefit, it will reduce the company value and profitability, in which this is called the entrenchment effect (Attig et al. 2008; Utama et al. 2017). In other words, when there is a large divergence on cash flow rights and control rights, the willingness to increase firm value is less restrained by the controlling shareholders (Claessens et al. 2002), thus reducing the performance.

Subsequently, having multiple large shareholders (MLS) helps to strengthen the monitoring role (Attig et al. 2009). The existence of MLS promotes the alleviation of the expropriation risk, especially those involving private benefits, since it will require mutual consent among the MLS. Furthermore, there will be a competition of control between the MLS which will help in providing check and balance between them.

\section{Hypothesis Development}

\section{Concentrated Ownership and Bank Profit- ability in Indonesia}

A study conducted by La Porta et al. (1999) discovered that concentrated ownership of dominant shareholders was commonly found within registered companies around the world. In addition, generally companies with concentrated ownership are followed by high control or control rights by 
controlling shareholders, in which the controlling rights possessed affect the company's performance (Claessens et al. 2000; Faccio and Lang 2002; Du and Dai 2005; La Porta et al.1999; AzofraPalenzuela and Santamaria-Mariscal 2007). The effect of concentrated ownership on company performance can cause two effects: namely monitoring fand expropriation effects.

Concentrated ownership can lead to monitoring effects when controlling shareholders utilize the power they have to carry out the monitoring role of the company. The intended monitoring is executed by a principal who in this case represents the concentrated shareholders ensuring that the manager will act according to the interest of the shareholders. Therefore, if the monitoring effect occurs, it is foreseen to possess a positive impact on company performance. Research related to monitoring effects is proven in studies conducted by Boussaada and Karmani (2015), Ozili and Uadiale (2017), and Yasser and Mamun (2017).

However, concentrated ownership can also have a negative impact, including the seizure of rights of minority shareholders by majority shareholders, or what is known as the expropriation effect. The controlling shareholder who acts as principal uses his power to seize the rights of minority shareholders who act as agents, by utilizing company resources and taking corporate actions for personal interests with no regard to the rights of minority shareholders. Research on the existence of the expropriation effect from concentrated ownership is evidenced by several previous studies (Bian and Deng 2017; Lee and Lee 2014). Furthermore, the expropriation could lead to a decrease in profitability due to the lack of shareholder protection. For example, banks with concentrated ownership usually tend to offer large loans to entities who have a connection with the banks' majority shareholders, which might sacrifice bank performance and profitability (Sapienza 2004).
In Indonesia, the emergence of the expropriation effect on concentrated ownership was expected to arise during the financial crisis that occurred in 1997. Many banks with concentrated ownership are closely related and negatively related to the implementation of good banking governance because they use their control to take advantage of private companies. This is also in line with the evidence found by Alimehmeti and Paletta (2012) and Bian and Deng (2017). This has also become the basis for BI to issue policies related to the maximum limit of share ownership in banks, namely PBI Number 14/8/PBI/2012 regarding Commercial Bank Share Ownership. BI issued the regulation with the aim of avoiding concentrated ownership so that it could improve the implementation of good governance as well as strengthen national banking endurance. However, because the function of BI to oversee banks has been transferred to the OJK, the regulation has changed to POJK No. 56/ POJK.03/2016 regarding Commercial Bank Share Ownership. This shows that the regulator wants banking ownership in Indonesia to not be concentrated in one particular party.

The regulations related to the bank share ownership limit issued by the OJK were legitimated in 2016, so for now the application of the OJK policy is suspected to have not been fully implemented by banks in Indonesia. This seems especially likely considering the difficulty and time required for shareholders to adjust their ownership structure according to the OJK regulations. This claim is also supported by the number of commercial banks in Indonesia which are still more than 100 in number (OJK2018), where Indonesia has the largest number of banks in Southeast Asia (Ananta 2019; Hariyanti 2018).

Based on these considerations, to address the first hypothesis, this study intends to test whether the ownership structure of banks in Indonesia is currently in accordance with OJK regulations without analyzing the composition of its share- 
holders. This study will also test whether concentrated ownership will pose a negative association with banking performance in Indonesia, as seen from OJK regulation efforts to limit bank ownership. Additionally, since a non-linear relationship between concentrated ownership and profitability will also be present due to the mixedeffects between the monitoring effects and expropriation effects, this study will also test the non-linear relationship between concentrated ownership and profitability.

\section{$\mathrm{H}_{1}$ : Concentrated ownership is nega- tively associated with bank profitability.}

\section{Profitability Difference in Concentrated Ownership of Financial Institutions and Non-Financial Institutions in Indonesian Banks}

OJK as a financial sector regulator in Indonesia seeks to consolidate banks in order to strengthen the banking capital structure in Indonesia. This regulator's efforts are reflected in POJK No. 56/POJK.03/2016 concerning Commercial Bank Share Ownership. This is intended to strengthen the banks, especially with increasing competition among banks. This OJK regulation provides the largest ownership limit on banks to financial institutions because it is expected that the limits of banking ownership can strengthen banking when dominated by financial institutions.

The expectation of a positive association between profitability and ownership of financial institutions in banks in Indonesia is supported by several previous studies, such as Shleifer and Vishny (1986), Kao et al. (2018), and Yasser and Mamun (2017). Shleifer and Vishny (1986) identified that institutional ownership can improve the efficiency and performance of companies with their ability to oversee managers and provide funds for companies in need. The results of this study are also referred to as active monitoring views.

Musallam et al. (2018) found that institutional ownership can result in a decrease in the performance of companies in
Indonesia, due to the inability of concentrated institutional owners to supervise managers. Elyasiani and Jia (2010) also found a negative relationship based on the exploitation view, in which institutional investors can side with the management to exploit minority shareholders and reduce company performance. Negative relationships also arise based on the view of passive monitoring, under which institutional owners are seen as short-term traders who only prioritize short-term profits to further their interests (David and Kochhar 1996)

Based on the OJK regulations related to banking ownership limitations and the inconsistency of research results, in the second hypothesis this study examines whether there are differences in performance between concentrated banks owned by financial institutions and those owned by non-financial institutions. In addition, this study also examines the application of the regulations for limiting share ownership of financial institutions and non-financial institutions in Indonesian banks according to POJK No. 56/POJK.03/2016 regarding "Maximum Share Ownership Limits". In this study, non-financial institutions include individuals.

\section{$\mathrm{H}_{2}$ : There is a significant difference in the association of profitability and concentrated ownership on financial institutions and non-fi- nancial institutions.}

The following is an overview of the research regarding the ramification of concentrated ownership on bank profitability. The independent variable is concentrated ownership, while bank performance is the dependent variable. Control variables are company size, company age, credit risk, company growth, and GDP, which are also described as influences on banking performance.

The first control variable, company size, is deemed to have the ability to influence firm performance due to the argument that large companies have more resources and thus have a competitive 


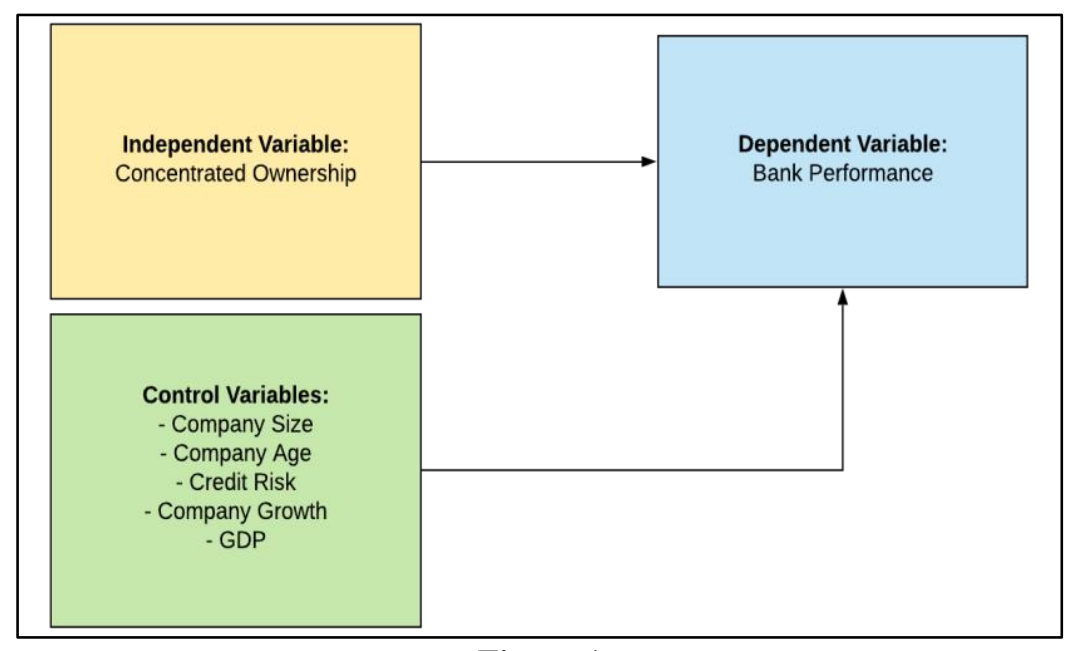

Figure 1

Research Framework

advantage to become profitable (Wahba 2008). Subsequently, similar reasons also explained the impact of company age on company performance. Mature companies are considered to have more expertise in the field, which boosts profitability. Another variable, company growth, positively affects performance. This is shown by the high growth that will increase the performance measured by profitability level (Le and Phan 2017). Credit risk could negatively affect company performance; research finds that a less profitable company usually conducts high-risk activities, therefore a high-risk company shows inferior performance (Menicucci and Paoluci 2016; Alu 2016). Lastly, the GDP growth rate controls company performance because it contributes to the development of the business environment and lowers the barrier bank entry (Liu and Wilson 2009).

\section{RESEARCH METHOD}

\section{Population and Sample}

The population of this research includes all commercial banks in Indonesia, both publicly listed on the Indonesia Stock Exchange (IDX) and non-public for the period of 2012 to 2018. The data used in this study is secondary data obtained from the IDX website, the website for each bank, and the website of the Ministry of Trade of the Republic of Indonesia. The criteria for inclusion in the sample are as follows: 1) a banking company in Indonesia that operated from 2012 to 2018 ; 2) a banking company that has published annual reports from 2012 to 2018; and 3) a banking company limited to the category of a commercial bank. Commercial banks whose ownership is concentrated by the central government and branch offices of banks domiciled abroad are excluded from the sample. This is done based on the criteria for ownership limits listed in POJK No. 56/ POJK.03/ 2016 regarding Commercial Bank Share Ownership.

\section{Data Analysis Method}

Below are all the models used in this study. Models 1 and 2 are used to test Hypothesis 1; while Models 3 and 4 are employed to test the possible non-linear relation between CON and ROE/ROA. Meanwhile, Models 5 and 6 are utilized to test Hypothesis 2. To prove Hypothesis $1, \beta_{1}$ is expected to be negative. Meanwhile for Hypothesis 2, it is expected that $\beta_{4}$ to be different from zero.

\section{Variable Operationalization}

The variables used in this study are divided into three categories: the dependent variable, the main independent variable, and the control variable. First, the dependent variable in this study is profitability, namely ROA and ROE. The main independent variable in this research is ownership and is concentrated in the form 
Table 1

Research Sample

\begin{tabular}{lcc}
\hline Sample Selection Criteria & $\begin{array}{c}\text { Number of } \\
\text { Companies }\end{array}$ & $\begin{array}{c}\text { Number of } \\
\text { Observations }\end{array}$ \\
\hline Commercial banks registered per 2018. & 115 & 805 \\
\hline Commercial banks owned by the central government. & $(4)$ & $(28)$ \\
\hline $\begin{array}{l}\text { Commercial banks which are branch offices of a bank } \\
\text { domiciled abroad. }\end{array}$ & $(9)$ & $(63)$ \\
\hline
\end{tabular}

Commercial banks that do not have complete data on

annual reports and/or financial reports for 2012 to 2018.

\section{Companies used as a sample}

93

651

Model 1:

Source: from data processed.

$$
\begin{aligned}
& R O A_{i t}=\beta_{0}+\beta_{1} \operatorname{CON}_{i t}+\beta_{2} F_{I N}+\beta_{3} I N D_{i t}+\beta_{4} \operatorname{SIZE}_{i t}+\beta_{5} A G E_{i t}+\beta_{6} N P L_{i t} \\
& +\beta_{7} G R O W T H_{i t}+\beta_{8} G D P_{i t}+\beta_{9} P U B L_{i t}+\varepsilon_{i t} \\
& R O E_{i t}=\beta_{0}+\beta_{1} \operatorname{CON}_{i t}+\beta_{2} F_{I N}+\beta_{3} I N D_{i t}+\beta_{4} \operatorname{SIZE}_{i t}+\beta_{5} A G E_{i t}+\beta_{6} N P L_{i t} \\
& +\beta_{7} G R O W T H_{i t}+\beta_{8} G D P_{i t}+\beta_{9} P U B L_{i t}+\varepsilon_{i t} \\
& R_{\text {ROA }}=\beta_{0}+\beta_{1} \text { CONPRCNT2 }_{i t}+\beta_{2} \text { FIN }_{i t}+\beta_{3} I N D_{i t}+\beta_{4} \operatorname{SIZE}_{i t}+\beta_{5} A G E_{i t}+\beta_{6} N P L_{i t} \\
& +\beta_{7} G R O W T H_{i t}+\beta_{8} G D P_{i t}+\beta_{9} P U B L_{i t}+\beta_{10} C O N P R C N T_{i t}+\varepsilon_{i t} \\
& R O E_{i t}=\beta_{0}+\beta_{1} C_{\text {ONPRCNT2 }}+\beta_{2} \text { FIN }_{i t}+\beta_{3} I N D_{i t}+\beta_{4} S I Z E_{i t}+\beta_{5} A G E_{i t}+\beta_{6} N P L_{i t} \\
& +\beta_{7} G R O W T H_{i t}+\beta_{8} G D P_{i t}+\beta_{9} P U B L_{i t}+\beta_{10} C O N P R C N T_{i t}+\varepsilon_{i t}
\end{aligned}
$$

$$
\begin{aligned}
R O A_{i t}=\beta_{0}+ & \beta_{1} \text { CON }_{i t}+\beta_{2} F_{I N}+\beta_{3} I N D_{i t}+\beta_{4} C O N * F I N_{i t}+\beta_{5} C O N * I N D_{i t}+\beta_{6} S_{I Z E_{i t}} \\
& +\beta_{7} A G E_{i t}+\beta_{8} N P L_{i t}+\beta_{9} G R O W T H_{i t}+\beta_{10} G D P_{i t}+\beta_{11} P U B L_{i t}+\varepsilon_{i t}
\end{aligned}
$$

Model 5:

Model 6:

$$
\begin{aligned}
R O E_{i t}=\beta_{0}+ & \beta_{1} \text { CON }_{i t}+\beta_{2} F_{I N}+\beta_{3} I N D_{i t}+\beta_{4} C O N * F I N_{i t}+\beta_{5} C O N * I N D_{i t}+\beta_{6} S_{I Z E_{i t}} \\
& +\beta_{7} A G E_{i t}+\beta_{8} N P L_{i t}+\beta_{9} G R O W T H_{i t}+\beta_{10} G D P_{i t}+\beta_{11} P U B L_{i t}+\varepsilon_{i t}
\end{aligned}
$$

\section{Explanation:}
$R O A_{i t}$
$R O E_{i t}$
Return on Assets bank (company) in year t.
CON $_{i t}$
Return on Equity bank (company) in year t.
: Concentrated ownership in year $\mathrm{t}$ (dummy variable; $1=$ ownership above $40 \%, 0=$ others).
CONPRCNT $T_{i t}$ : Concentrated ownership in year $\mathrm{t}$ (dummy variable; $1=$ ownership above $40 \%, 0=$ others).
CONPRCNT2 $2_{i}$ : Concentrated ownership in year $\mathrm{t}$ (dummy variable; $1=$ ownership above $40 \%, 0=$ others).
FIN $_{\text {it }} \quad$ : Concentrated financial ownership in year $\mathrm{t}$ (dummy variable; $1=$ financial institutions ownership, $0=$ others)
IND $\quad$ it $\quad$ Concentrated individual ownership in year $\mathrm{t}($ dummy variable $; 1=$ individual ownership, $0=$ others ).
$S I Z E_{i t} \quad:$ Company size in year t.
$A G E_{i t} \quad:$ The age of the company since its establishment up to year t.
$N P L_{i t} \quad:$ Credit risk in year $\mathrm{t}$.
GROWTH $H_{i t} \quad$ : The amount of sales growth from the company every year.
$P D B_{i t} \quad$ : Indonesia's Growth Domestic Product (GDP) at year t. 
Table 2

Variable Operationalization

\begin{tabular}{|c|c|c|c|}
\hline Variable & Definition & Measurement & $\begin{array}{l}\text { Literature } \\
\text { Source }\end{array}$ \\
\hline \multicolumn{4}{|c|}{ Dependent Variable } \\
\hline $\begin{array}{l}\text { Return on Assets } \\
\text { (ROA) }\end{array}$ & $\begin{array}{l}\text { The ratio measures the ability } \\
\text { of banks to generate profits } \\
\text { from their assets. }\end{array}$ & $\begin{array}{l}R_{O A_{i t}} \\
=\frac{\text { Profit before tax }_{i t}}{\text { Average total assets }} \text { it }\end{array}$ & $\begin{array}{l}\text { Circular Letter } \\
\text { from Financial } \\
\text { Service } \\
\text { Authority (OJK) } \\
\text { No. } \\
11 / \text { SEOJK.03/20 } \\
15\end{array}$ \\
\hline $\begin{array}{l}\text { Return on Equity } \\
\text { (ROE) }\end{array}$ & $\begin{array}{l}\text { The ratio measures the ability } \\
\text { of banks to generate profits } \\
\text { from their equity. }\end{array}$ & $\begin{array}{l}R O E_{i t} \\
=\frac{\text { Profit after tax }}{\text { Average total equity }}\end{array}$ & $\begin{array}{l}\text { Circular Letter } \\
\text { from Financial } \\
\text { Service } \\
\text { Authority (OJK) } \\
\text { No. } \\
11 / \text { SEOJK.03/20 } \\
15\end{array}$ \\
\hline
\end{tabular}

Main Independent Variable

\begin{tabular}{|c|c|c|c|}
\hline $\begin{array}{l}\text { Concentrated } \\
\text { Ownership } \\
\text { (CON, } \\
\text { CONPRCNT) }\end{array}$ & $\begin{array}{l}\text { Share ownership in banks is } \\
\text { concentrated, which means } \\
\text { that the direct largest } \\
\text { ownership of shares } \\
\text { represents a significant } \\
\text { percentage of ownership. }\end{array}$ & $\begin{array}{l}\text { Direct ownership of the } \\
\text { largest shareholder above } \\
40 \% \text { is included in } \\
\text { concentrated ownership. }\end{array}$ & $\begin{array}{l}\text { POJK No. } \\
\text { 56/POJK.03/201 } \\
6\end{array}$ \\
\hline $\begin{array}{l}\text { Financial } \\
\text { Institutions } \\
\text { (FIN) }\end{array}$ & $\begin{array}{l}\text { The identity of the largest } \\
\text { direct owner is financial } \\
\text { institutions. Financial } \\
\text { institutions ownership is the } \\
\text { fraction of a firm's shares that } \\
\text { are held by institutional } \\
\text { investors. Financial } \\
\text { institutions include banks, } \\
\text { insurance companies, and } \\
\text { pension funds. }\end{array}$ & $\begin{array}{l}\text { Dummy variable of financial } \\
\text { institutions ownership. }\end{array}$ & $\begin{array}{l}\text { Chung and } \\
\text { Zhang, 2011; } \\
\text { Del Guercio, } \\
1996\end{array}$ \\
\hline $\begin{array}{l}\text { Individuals } \\
\text { (IND) }\end{array}$ & $\begin{array}{l}\text { The identity of the largest } \\
\text { direct owner is individuals. } \\
\text { Individual ownership is also } \\
\text { the ultimate owner since they } \\
\text { control themselves as a } \\
\text { person. }\end{array}$ & $\begin{array}{l}\text { Dummy variable of } \\
\text { individual ownership }\end{array}$ & $\begin{array}{l}\text { La Porta et al. } \\
1999\end{array}$ \\
\hline \multicolumn{4}{|c|}{ Control Variable } \\
\hline $\begin{array}{l}\text { Company Size } \\
\text { (SIZE) }\end{array}$ & $\begin{array}{l}\text { The amount of assets owned } \\
\text { by the bank. }\end{array}$ & $\operatorname{SIZE}_{i t}=$ LogAsset $_{i t}$ & $\begin{array}{l}\text { Ehsan and Javid } \\
(2015) \text {; Lepore }\end{array}$ \\
\hline
\end{tabular}




\begin{tabular}{|c|c|c|c|}
\hline & & & $\begin{array}{l}\text { et al. (2017); } \\
\text { Yasser and } \\
\text { Mamun (2017) }\end{array}$ \\
\hline $\begin{array}{l}\text { Company Age } \\
\text { (AGE) }\end{array}$ & $\begin{array}{l}\text { The bank's age from the } \\
\text { beginning it was formed until } \\
\text { t. }\end{array}$ & $\begin{array}{l}A G E_{i t} \\
=\text { Year }_{i t} \\
- \text { Year of establishment }_{i}\end{array}$ & $\begin{array}{l}\text { Michaelas et al. } \\
\text { (1999) }\end{array}$ \\
\hline $\begin{array}{l}\text { Growth } \\
\text { (GROWTH) }\end{array}$ & $\begin{array}{l}\text { Bank's sales growth every } \\
\text { year. }\end{array}$ & $\begin{array}{l}\text { GROWTH }_{i t} \\
=\frac{\text { Revenue }_{i t}-\text { Revenue }_{i t-1}}{\text { Revenue }_{i t}}\end{array}$ & $\begin{array}{l}\text { Le and Phan } \\
(2017)\end{array}$ \\
\hline NPL $\operatorname{gross}(\mathrm{NPL})$ & $\begin{array}{l}\text { Non-performing loans that } \\
\text { are substandard quality, } \\
\text { doubtful, and congested. }\end{array}$ & 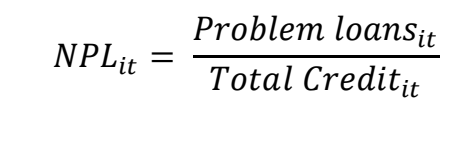 & $\begin{array}{l}\text { Menicucci and } \\
\text { Paolucci (2016); } \\
\text { Alu (2016) }\end{array}$ \\
\hline $\begin{array}{l}\text { Gross Domestic } \\
\text { Growth (GDP) }\end{array}$ & $\begin{array}{l}\text { Gross Domestic Product } \\
\text { (GDP) growth in Indonesia. }\end{array}$ & $G D P_{i t}=\frac{G D P_{i t}-G D P_{i t-1}}{G D P_{i t-1}}$ & $\begin{array}{l}\text { Boussaada and } \\
\text { Karmani (2015) }\end{array}$ \\
\hline $\begin{array}{l}\text { The type of Banks } \\
\text { (PUBL) }\end{array}$ & $\begin{array}{l}\text { The type of the bank (Public } \\
\text { or Non-Public Banks) }\end{array}$ & $\begin{array}{l}\text { Dummy variable of the type } \\
\text { of Banks }\end{array}$ & \\
\hline
\end{tabular}

Source: from various sources

of a dummy variable. Finally, there are five control variables in this study, namely SIZE, AGE, GROWTH, NPL, and GDP.

This study uses unbalanced panel data. In determining the appropriate regression model, this study utilizes three tests of model accuracy, namely the Chow test, the Hausman test, and the Lagrange Multiplier (LM) test. The results of the Chow test and the Hausman test recommend that this study uses a fixed effect model, while the results of the LM test recommend this study uses the random effects model. Thus, according to these accuracy tests, the fixed effect model is the suitable method for this study. However, Gujarati and Porter (2009) claim that there are several issues that need to be considered if a researcher wants to use the fixed effect model, or what is widely known as the Least-Squares Dummy Variable (LSDV) model. One such issue is that if too many dummy variables are in the study, there will be a problem with the degree of freedom. This is because the research will experience insufficient observations to perform meaningful statistical analysis. Simply put, the use of the fixed effect model in studies that use too many dummy variables can cause problems in the degree of freedom. According to Gujarati and Porter (2009), the use of the LSDV technique distinguishes individuals (banks) that use dummy variables. Given that this study uses a large number of banks, it is very likely that there will be a problem with the degree of freedom. This issue is also in line with Nachrowi and Usman (2006), in particular if the panel data collected has an individual number (i) greater than the amount of time (t), it is recommended that researchers use the random effects method. As mentioned earlier, the number of individuals (banks) in this study totaled 93 banks, while the length of time of this study was only 7 years. In other words, the random effects method tends to be more suitable for this study. In addition, the fixed effects method accommodates the existence of individual differences but cannot accommodate differences between times (Gujarati and Porter 2009). This study has data that changes every year (time variant), such as SIZE which tends to experience growth every year, AGE that experiences growth every year, NPL which sometimes fluctuates every year, GROWTH that varies 
Table 3

Data Description

\begin{tabular}{clc}
\hline \multicolumn{2}{c}{ Banks } & Proportions \\
\hline & Public & $23.66 \%$ \\
Type of Bank & $\begin{array}{c}\text { Non-Public } \\
\text { Total } \\
\text { Observations }\end{array}$ & $76.34 \%$ \\
& Financial & $100.00 \%$ \\
\hline Concentrated & Non-Financial & $56.29 \%$ \\
Ownership & Individual & $58.05 \%$ \\
& Total & $5.66 \%$ \\
& observations & $100.00 \%$ \\
\hline
\end{tabular}

Table 4

Descriptive Statistics

\begin{tabular}{lccccc}
\hline \multicolumn{1}{c}{ Variable } & N & Mean & Std. Dev. & Min. & Max. \\
\hline ROA & 644 & 0.0159 & 0.0345 & -0.2013 & 0.7100 \\
ROE & 644 & 0.0955 & 0.1508 & -1.4248 & 0.5798 \\
CON & 636 & 0.7406 & 0.4387 & 0.0000 & 1.000 \\
CONPRCNT & 636 & 0.6195 & 0.2630 & 0.1246 & 1.000 \\
FIN & 636 & 0.5629 & 0.4964 & 0.0000 & 1.000 \\
IND & 636 & 0.0566 & 0.2313 & 0.0000 & 1.000 \\
SIZE & 644 & 30.1877 & 1.4338 & 26.8110 & 34.3462 \\
AGE & 651 & 39.2304 & 16.5954 & 2.0000 & 105.000 \\
NPL & 642 & 0.0279 & 0.0309 & 0.0000 & 0.4399 \\
GROWTH & 619 & 0.1643 & 0.2957 & -0.6570 & 3.0790 \\
GDP & 651 & 0.0525 & 0.0038 & 0.0488 & 0.0603
\end{tabular}

$\mathrm{ROA}=$ profit before tax / average total assets; $\mathrm{ROE}=$ profit after tax / average total equity; $\mathrm{CON}=$ dummy variable $(1=$ share ownership above $40 \%, 0=$ others $)$; SIZE = company size; AGE = company age; NPL = credit risk; GROWTH = company revenue growth; GDP = GDP growth.

Source: from data processed.

every year, and also GDP that experiences movement every year. In other words, the data from this study are less suitable for the fixed effects model. Another idea that supports the use of the random effects model is that this research data has problem of heteroscedasticity. This problem arises when errors from the data model do not have constant variance. The use of the Random Effect method can overcome this problem (Gujarati and Porter2009). Several previous studies that investigated the association of ownership structure and company performance also used the random effects regression model (Gedajlovic and Shapiro 2002; Musallam et al. 2018). Because of these aspects, it is determined that the model to be used is the random effects model.

The classic assumption test results in this study stated that the data were normally distributed, had no symptoms of autocorrelation or symptoms of multicollinearity, but had symptoms of heteroscedasticity. Since this study uses the random effects method, the symptoms of heteroscedasticity can be overcome (Gujarati and Porter 2009). 
Table 5

Hypothesis 1 Test Results

\begin{tabular}{|c|c|c|c|c|c|c|c|c|}
\hline & \multicolumn{2}{|c|}{$\begin{array}{c}\text { Model } 1 \\
\text { ROA }\end{array}$} & \multicolumn{2}{|c|}{$\begin{array}{c}\text { Model } 2 \\
\text { ROE }\end{array}$} & \multicolumn{2}{|c|}{$\begin{array}{c}\text { Model } 3 \\
\text { ROA }\end{array}$} & \multicolumn{2}{|c|}{$\begin{array}{l}\text { Model } 4 \\
\text { ROE }\end{array}$} \\
\hline & Coefficient & $p$-value & Coefficient & $p$-value & Coefficient & $p$-value & Coefficient & p-value \\
\hline $\mathrm{CON}$ & -0.0010 & 0.599 & -0.0128 & 0.235 & & & & \\
\hline CONPRCNT2 & & & & & -0.0035 & 0.248 & -0.0349 & 0.068 \\
\hline FIN & -0.0049 & $0.023 * *$ & -0.0651 & $0.000 * * *$ & -0.0042 & $0.062 *$ & -0.0601 & $0.000^{* * *}$ \\
\hline IND & 0.0035 & 0.370 & -0.0532 & $0.025 * *$ & 0.0030 & 0.439 & -0.0555 & 0.019 \\
\hline SIZE & 0.0046 & $0.000^{* * *}$ & 0.0352 & $0.000 * * *$ & 0.0048 & $0.000^{* * *}$ & 0.0364 & $0.000^{* * *}$ \\
\hline AGE & 0.0002 & $0.012 * *$ & 0.0006 & 0.211 & 0.0001 & 0.036 & 0.0004 & 0.425 \\
\hline NPL & -0.3818 & $0.000 * * *$ & -2.0691 & $0.000 * * *$ & -0.3785 & $0.000^{* * *}$ & -2.0577 & $0.000 * * *$ \\
\hline GROWTH & 0.0111 & $0.000 * * *$ & 0.0829 & $0.000 * * *$ & 0.0112 & $0.000^{* * *}$ & 0.0837 & $0.000 * * *$ \\
\hline GDP & 0.6889 & $0.000 * * *$ & 7.3936 & $0.000 * * *$ & 0.6813 & $0.000 * * *$ & 7.3126 & $0.000 * * *$ \\
\hline PUBL & -0.0122 & $0.000^{* * *}$ & -0.0701 & $0.000 * * *$ & -0.0131 & $0.000^{* * *}$ & -0.0768 & $0.000^{* * *}$ \\
\hline CONPRCNT & & & & & -0.0110 & 0.117 & -0.0644 & 0.130 \\
\hline _cons & -0.1516 & $0.000 * * *$ & -1.2637 & $0.000 * * *$ & -0.1518 & $0.000^{* * *}$ & -1.2671 & $0.000 * * *$ \\
\hline Prob >chi 2 & \multicolumn{2}{|c|}{0.0000} & \multicolumn{2}{|c|}{0.0000} & \multicolumn{2}{|c|}{0.0000} & \multicolumn{2}{|c|}{0.0000} \\
\hline Adj R-sq & \multicolumn{2}{|c|}{0.4351} & \multicolumn{2}{|c|}{0.4985} & \multicolumn{2}{|c|}{0.4465} & \multicolumn{2}{|c|}{0.5121} \\
\hline
\end{tabular}

$P$-value at: $* * * \alpha=1 \%, * * \alpha=5 \%, * \alpha=10 \%$. ROA $=$ profit before tax $/$ average total assets; ROE $=$ profit after tax / average total equity; $\mathrm{CON}=$ dummy variable $(1=$ share ownership above $40 \%, 0=$ others $)$; CONPRCNT2 = quadratic value of the largest amount of concentrated ownership; FIN = dummy variable $(1=$ largest share owned by financial institutions, $0=$ others $)$; IND = dummy variable $(1=$ largest share owned by individuals, $0=$ others $)$; SIZE = company size; $\mathrm{AGE}=$ company age; NPL = credit risk; GROWTH = company revenue growth; GDP = GDP growth; PUBL = dummy variable $(1=$ public bank, $0=$ others $)$; CONPRCNT $=$ mean-adjusted value of the largest amount of concentrated ownership.

Source: from data processed.

\section{RESULT AND ANALYSIS}

Table 3 depicts that the majority of the banks in the observations are non-public banks (76.34\%). $56.29 \%$ of the observed banks are owned by financial institutions and $38.05 \%$ are owned by non-financial institutions. Meanwhile, only $5.66 \%$ of the observed banks are owned by individuals. Table 4 shows the results of the descriptive statistics from the studies on 93 banks with651 observations. The average of banking performance in the form of ROA and ROE are 0.0159 and 0.0955, respectively. Furthermore, from the result of the descriptive statistics, it is also insinuated that there are some observations with a negative value of ROA and ROE. The negative values on these variables are due to the fact that the banks had negative returns or suffered a loss during the observation period. These bank-years with negative ROA and ROE values are still used as observations because although showing negative returns, the values of the equity are still positive. CON showed a mean of 0.7406 , which means $74.06 \%$ of the observations have direct ownership of more than $40 \%$. The smallest value of the CONPRCNT variable is 0.1246 , while the largest is 1 , which means some banks are $100 \%$ owned and concentrated by one party such as Bank BRI Syariah, Bank Syariah Mandiri (Persero) Tbk, and Bank BCA Syariah. The average CONPRCNT variable is 0.6195 , meaning that the average concentration of commercial banks in Indonesia for the past seven years is 
$61.95 \%$. Based on the variables used in the test, the average standard deviation is in the range of 0.0038 to 1.4338 , except for the AGE variable, which records the largest standard deviation value of 16.5954 . This can be due to the varied age of the banks, of which there are recently established banks such as Bank BNI Syariah and Bank BCA Syariah. There are also banks that have been established for a long length of time, such as the QNB Bank.

Table 5 shows the results of Hypothesis 1 testing regarding the association of concentrated ownership and banking performance in Indonesia. The test results indicate the opposite results to previous studies, namely that concentrated ownership is not significantly associated with banking performance in the form of ROA and ROE, indicated by the p-value, which is above 0.1 . Therefore, Hypothesis 1 is rejected.

Test results on Model 1 and Model 2 are the opposite of the previous studies conducted in developing countries such as Korea (Lee and Lee 2014), and China (Bian and Deng 2017). Usually there is a possibility of a more dominant expropriation effect in Indonesia as a developing country. This is possible given that investor protection and the regulation of corporate governance in developing countries are still very lacking compared to developed countries (La Porta et al.2002). However, it can also be assumed that the regulation issued by the regulator may have decreased the negative effect of concentrated ownership, thus resulting in no significant relationship between concentrated ownership and bank profitability in Indonesia.

Furthermore, Model 3 and Model 4 exhibit mixed results. Model 3 does not find the mixed-effects between monitoring effects and expropriation effects with regard to the relationship between concentrated ownership and bank performance in Indonesia, whereas Model 4 does. This result is portrayed by the insignificant result of the CONPRCNT2, which represents a non-linear relationship. This result for
Model 4 signifies that there is a mixedeffect between monitoring effects and expropriation effects on the relationship between concentrated ownership and bank performance measured by ROE. Therefore, these mixed-effects might also explain why there is no significant relation between concentrated ownership and bank performance. Since both effects exist, they might offset one another, resulting in no significant relation.

These findings of the insignificant relationship of concentrated ownership and profitability on Model 1 and Model 2 are also driven by the concentrated average ownership factor of $61.95 \%$, which is still far above the limit set in the POJK No. 56/POJK.03/2016 on Shared Ownership of Commercial Banks with regard to the limitation of concentrated ownership in Indonesia, specifically by $40 \%$. This raises the possibility of expropriation of larger minority shareholders in Indonesia. However, the large concentrated ownership could also increase the monitoring effect by the majority shareholders. As such, they can help oversee the decision-making process. Therefore, as explained above, these two effects completed one another and caused no overall significant relation on concentrated ownership and bank performance.

In testing, the control variables of SIZE, AGE, GROWTH, and GDP give a significant positive after effect on each ROA and ROE model. These are in contrast to the NPL and PUBL variables, which possess significant negative effects on the ROA and ROE variables. The result on PUBL variables insinuates that the public banks' profitability is not higher than the non-public banks, thus supporting the previous statement that the performance of non-public banks is more superior. This may be caused by the better asset utilization and managerial performance of non-public banks (Koley 2019). The test on Model 6 and Model 7 (on the testing of Hypothesis 2) also confirmed the same result regarding public and non-public banks. 
Table 6

Average Ownership of the Largest Shareholder in Banking Industry in Indonesia 2012 - 2018

\begin{tabular}{|c|c|c|c|c|c|}
\hline \multirow[t]{8}{*}{ Year } & \multicolumn{4}{|c|}{ CONPRCNT Average } & \\
\hline & \multicolumn{2}{|c|}{2012} & \multicolumn{2}{|c|}{$65.26 \%$} & \\
\hline & \multicolumn{2}{|c|}{2013} & \multicolumn{2}{|c|}{$62.89 \%$} & \\
\hline & \multicolumn{2}{|c|}{2014} & \multicolumn{2}{|c|}{$60.69 \%$} & \\
\hline & \multicolumn{2}{|c|}{2015} & \multicolumn{2}{|c|}{$60.82 \%$} & \\
\hline & \multicolumn{2}{|c|}{2016} & \multicolumn{2}{|c|}{$60.93 \%$} & \\
\hline & \multicolumn{2}{|c|}{2017} & \multicolumn{2}{|c|}{$61.01 \%$} & \\
\hline & & & \multicolumn{2}{|c|}{$62.23 \%$} & \\
\hline - & \multicolumn{5}{|c|}{$\begin{array}{r}\text { CONPRCNT }=\text { the percentage ownership of the largest shareholder } \\
\text { Source: from data processed }\end{array}$} \\
\hline & & & \multicolumn{3}{|c|}{ Source: from data processed } \\
\hline & \multicolumn{5}{|c|}{ Table 7} \\
\hline & \multicolumn{5}{|c|}{ Hypothesis 2 Test Results (regression) } \\
\hline & & \multicolumn{2}{|c|}{ Model 5} & \multicolumn{2}{|c|}{ Model 6} \\
\hline & & \multicolumn{2}{|c|}{ ROA } & \multicolumn{2}{|c|}{ ROE } \\
\hline & & Coefficient & p-value & Coefficient & p-value \\
\hline & $\mathrm{CON}$ & -0.0033 & 0.181 & -0.0142 & 0.335 \\
\hline & FIN & -0.0054 & 0.131 & -0.0551 & $0.009 * * *$ \\
\hline & IND & -0.0061 & 0.227 & -0.0785 & $0.008 * * *$ \\
\hline & $\mathrm{CON} * \mathrm{FIN}$ & 0.0016 & 0.677 & -0.0106 & 0.641 \\
\hline & CON*IND & 0.0167 & $0.004 * * *$ & 0.0462 & 0.155 \\
\hline & SIZE & 0.0048 & $0.000 * * *$ & 0.0360 & $0.000 * * *$ \\
\hline & AGE & 0.0002 & $0.011 * *$ & 0.0006 & 0.201 \\
\hline & NPL & -0.3773 & $0.000 * * *$ & -2.0499 & $0.000 * * *$ \\
\hline & GROWTH & 0.0108 & $0.000 * * *$ & 0.0816 & $0.000 * * *$ \\
\hline & GDP & 0.6980 & $0.000 * * *$ & 7.4101 & $0.000 * * *$ \\
\hline & PUBL & -0.0125 & $0.000 * * *$ & -0.0714 & $0.000 * * *$ \\
\hline & _cons & -0.1559 & $0.000 * * *$ & -1.2880 & $0.000 * * *$ \\
\hline & \multicolumn{2}{|l|}{ Prob > chi2 } & 0.0000 & \multicolumn{2}{|c|}{0.0000} \\
\hline & Adj R-sq & \multicolumn{2}{|c|}{0.4494} & \multicolumn{2}{|c|}{0.5049} \\
\hline
\end{tabular}

$P$-value at: $* * * \alpha=1 \%, * * \alpha=5 \%, * \alpha=10 \%$. ROA = profit before tax / average total assets; ROE = profit after tax / average total equity; FIN = dummy variable $(1=$ largest share owned by financial institutions, $0=$ others $)$; IND = dummy variable $(1=$ largest share owned by individuals, $0=$ others $)$; SIZE = company size; AGE = company age; $\mathrm{NPL}=$ credit risk; GROWTH = company revenue growth; GDP = GDP growth; PUBL = dummy variable $(1=$ public bank, $0=$ others $)$.

Source: from data processed.

Table 6 shows the average concentrated ownership in banks in Indonesia each year for the period 2012 to 2018; it can be seen that the number of CONPRCNT ranges from $60 \%$ upward. This value is still far above the limit set by OJK in the POJK No. 56/POJK.03/2016 regarding Share Ownership of Commercial Banks, so this discovery can be a reference for regulators to intensify the application of these limits.
In addition, the regulator can also simplify the administrative stages for purchasing shares or issuing shares for Initial Public Offering (IPO) so that it can attract new investors to invest their capital. This can also encourage the implementation of POJK No. 56/POJK.03/2016 regarding Share Ownership of Commercial Banks, which not only seeks bank consolidation, but also dispersed ownership in banking. 
Table 7 portrays the regression test results of Hypothesis 2 regarding the difference in profitability in concentrated ownership held by financial and non-financial institutions. In this test, individual ownership is excluded from non-financial institutions. The regression on Table 7 insinuates that the concentrated ownership by financial institutions is only negatively and significantly associated with the bank profitability measured by ROE. However, when testing the relation on the concentrated ownership and its type of ownership institution (CON*FIN), it does not show a significant result. Thus, Hypothesis 2 is rejected since there is no difference in the association of profitability and concentrated ownership on financial and non-financial institutions.

Usually, the presence of financial institution ownership might help to ensure the right decision-making by the management, as well as having a role to oversee the management (Musallam et al. 2018). Ownership by financial institutions could reduce acts of exploitation. Elyasiani and Jia (2010) who studied the exploitation view state that it is possible for majority shareholders to exploit minority shareholders to enable the company to have reduced performance. However, financial institutional shareholders also do not always have a positive effect in holding the role of majority shareholders because it allows them to only carry out passive monitoring; this is also referred to as the passive monitoring view, as found by David and Kochtar (1996).Under this view, institutional shareholders who have shares concentrated in Indonesian banks may only play a role as short-term traders who prioritize short-term profits, thus their existence as shareholders may not make any difference on bank performance.

\section{CONCLUSION}

The results of the study indicate that concentrated ownership is not associated with bank performance. Furthermore, testing of the non-linear relationship indicates the absence of a non-linear relation between concentrated ownership and profitability. Hence, this non-significant relationship indicates that there may be a mixedeffect of expropriation and monitoring motives that offset one another, causing no relation between concentrated ownership and bank performance in Indonesia. Thus, based on the results of this study, POJK No. 56/POJK.03/2016 concerning Commercial Bank Share Ownership, in which the OJK's desire to limit the ownership of shares of commercial banks, may not be effective in increasing bank profitability (ROA, ROE).

The regression test to examine whether there is any effect of financial institutions as the largest shareholder on the relation between concentrated ownership and profitability shows that the effect is not significant. This is presumably because institutional shareholders tend to hold shortterm roles as traders who are only concerned with short-term profits, and not fully uphold the overseeing role.

If it is associated with POJK No. 56/POJK.03/2016 concerning Commercial Bank Share Ownership, the average share of the largest ownership of commercial banks is far above the limitation set by the regulator. Statistically, the average ownership concentrated in Indonesian banking is currently still at $61.95 \%$, while the limitation of the regulator's maximum ownership limit is at 40 percent.

There are some limitations to this study. Initially, this study only divides concentrated ownership as financial and nonfinancial institutions, and was not fully in accordance with the division determined by POJK No. 56/POJK.03/2016 concerning Commercial Bank Share Ownership. Under this regulation, there is also a division of ownership by non-financial institutions and individuals. Referring to POJK No. 56/POJK.03/2016 concerning Commercial Bank Share Ownership, this study only explored the ownership limits concentrated in the category of financial and non-financial institutions by $40 \%$. Secondly, this research 
does not take the divergence between ownership or cash flow right and control or voting rights into account, although there is existing literature regarding this topic. Third, this study only used the direct or the largest shareholder as a measurement for concentrated ownership and did not examine the role of the multiple large shareholders.

POJK No. 56/POJK.03/2016 concerning Commercial Bank Share Ownership also involves the soundness of banks in implementing this regulation. However, this study did not include the factor of bank soundness. This study also did not divide the sample of banks according to the Bank Umum berdasarkan Kegiatan Usaha $(B U K U)$ bank categories and was only conducted in Indonesia and not compared with banks in other countries.

There are a few recommendations for further research; research related to concentrated ownership limits can also explore the $30 \%$ ownership limit category for ownership of non-financial legal entities and $20 \%$ for individual ownership, as regulated by POJK No. 56/POJK.03/2016 concerning Commercial Bank Share Ownership. Additional analysis can also be conducted related to the influence of the composition of ownership and existence of multiple large shareholders on banking performance for more in depth research on the relationship of concentrated ownership to banking performance. Future study can also add other factors to the levels of bank health in the study so that it is more in line with POJK No. 56/POJK.03/2016 concerning Commercial Bank Share Ownership. Further research can also use other measurements of banking performance in addition to ROA and ROE so that the effect of concentrated ownership on other banking performance proxies can be seen (one example is Tobin's Q). This may reduce the bias in the measurements since the accounting-based measure can be easily manipulated by the management while the market data cannot (Groß 2007). In addition to conducting a different test for
Hypothesis 2, a regression test can be carried out relating to the relationship between concentrated ownership of financial institutions to banking performance. This can enrich the existing research on concentrated ownership relationships on banking performance in terms of management by financial institutions in banking. Future researchers can also divide the sample of banks based on the bank categories of BUKU 1,2,3, and 4 to gain better insight on whether there is a relationship between concentrated ownership and bank profitability. Furthermore, subsequent research can also broaden the scope of research in banking throughout ASEAN in order to see how banks in Indonesia compare to banks in other ASEAN countries. ASEAN banking is considered important due to the endorsement of the ASEAN Banking Integration Framework, which is expected to harmonize banking regulations.

\section{REFERENCES}

Alu, E. L. M. N. A. A. 2016. Nonperforming Loans and Bank Profitability: Evidence From An Emerging Market. African Journal of Economic and Management Studies, 7 (4).

Ananta, Y. 2019. Terlalu Banyak, Jumlah Perbankan di RI Capai 1.712 Diunduhtanggal 9 Mei 2019 https://www.cnbcindonesia.com/ma rket/20190318162202-17-

61354/terlalu-banyak-jumlah-perbankan-di-ri-capai-1712-bank

Alimehmeti, G., and A. Paletta. 2012. Ownership Concentration and Effects Over Firm Performance: Evidences from Italy. European Scientific Journal October, 8 (22), 39-49.

Attig, N., S. El Ghoul, and O. Guedhami. 2009. Do Multiple Large Shareholders Play A Corporate Governance Role? Evidence From East Asia.

Attig, N., O. Guedhami, and D. Mishra. 2008. Multiple Large Shareholders, 
Control Contests, And Implied Cost Of Equity. Journal of Corporate Finance, 14 (5), 721-737.

Azofra-Palenzuela, V. A., and M. Santamaría-Mariscal. 2008. The Ultimate Controlling Owner of Spanish Commercial Banks.

Bian, W., and C. Deng. 2017. Ownership Dispersion and Bank Performance: Evidence from China. Finance Research Letters, 22, 49-52.

Bolton, P. 2002. Banking in Emerging Markets. Journal of Financial Intermediation, 11, 362-365.

Boussaada, R., and M. Karmani. 2015. Ownership Concentration and Bank Performance: Evidence from MENA Banks. International Journal of Business and Management, 10 (3).

Chan, L. K. C., and J. Lakonishok. 1995. The Behavior of Stock Prices Around Institutional Trades. The Journal of Finance, 50 (4), 11471174.

Chung, K. H., and H. Zhang. 2011. Corporate Governance and Institutional Ownership. The Journal of Financial and Quantitative Analysis, 46 (1), 247-273.

Claessens, S. et al. 2002. Disentangling The Incentive and Entrenchment Effects of Large Shareholdin. Journal of Finance, 57 (6), 2741-2771.

Claessens, S., S. Djankov, and L. H. P. Lang . 2002. Expropriation of Minority Shareholders in East Asia. Journal of Finance, 57

Cornett, M. M. et al. 2007. The Impact of Institutional Ownership on Corporate Operating Performance. Journal of Banking and Finance, 31, 1771-1794.

David, P., and R. Kochhar. 1996. Barriers To Effective Corporate Governance By Institutional Investors: Implications For Theory And Practice. European Management Journal, 14, 457-466.
Del Guercio, D. 1996. The Distorting Effect of the Prudent-Man Laws on Institutional Equity Investment. Journal of Financial Economics, 40, 31-62.

Demsetz, H., and K. Lehn. 1985. The Structure Of Corporate Ownership: Causes And Consequences. Journal of Political Economy, 93 (6), 11551177.

Du, J., and Y. Dai. 2005. Ultimate Corporate Ownership And Capital Structures: Evidence From East Asian Economies. Corporate Governance, 13 (1), 60-71.

Ehsan, S., and A. Y. Javid. 2015. Ownership Structure and Bank Performance: A Case of Banking Industry in Pakistan.Journal of Business \& Economics, 7 (1), 1-27.

Elyasiani, E., and J. Jia. 2010. Distribution Of Institutional Ownership And Corporate firm Performance. Journal of Banking and Finance, 34, 606-620.

Enqvist, J. 2005. Managerial Ownership, Controlling Shareholders And Firm Performance. Available at: www.efmaefm.org/efma2005/paper s/75enqvist_paper

Faccio, M, and L. H. P. Lang. 2002. The Ultimate Ownership Of Western European Corporations. Journal of Financial Economics, 65, 365-395.

Faccio, M., and D. Stolin. 2006. Expropriation vs. Proportional Sharing in Corporate Acquisitions. The Journal of Business, 79 (3), 1413-1444.

Gedajlovic, E., and D. M. Shapiro. 2002. Ownership Structure and Firm Profitability in Japan. The Academy of Management Journal, 45 (3), 565575.

Groß, K. 2007. Equity Ownership and Performance: An Empirical Study of German Traded Companies. New York: Physica-Verlag Heidelberg.

Gujarati, D. N., and D. C. Porter. 2009. Basic Econometrics. New York: McGraw-Hill. 
Hariyanti, D. 2018. Konsolidasi Perbankan, Modal Makin Kuat dan Perusahaan Ramping. Katadata. Diunduh tanggal 9 Mei 2019, https://katadata.co.id/berita/2018/08 /07/konsolidasi-perbankan- motivasi-utamanya-sehat-rampingcuma-bonus

Jensen, M. C., and W. H. Meckling. 1976. Theory of the Firm: Managerial Behavior, Agency Cost, and Ownership Structure. Journal of Financial Economics 3, 305-360.

Kao, M., L. Hodgkinson, and A. Jaafar. 2019. Ownership Structure, Board of Directors and Firm Performance: Evidence from Taiwan. The International Journal of Business in Society, 19 (1), 189-216.

Koley, J. 2019. Analysis of Financial Position and Performance of Public and Private Sector Banks in India: A Comparative Study on SBI and HDFC Bank. Journal of Netaji Subhas Open University, 2 (1).

King, M., and E. Santor. 2007. Family Values: Ownership Structure And Performance Of Canadian Firms. Available at: https://econpapers.repec.org/RePEc:eee:jbfina:v:3 2:y:2008:i:11:p:2423-2432

La Porta, R.. 2002. Investor Protection And Corporate Valuation. Journal of Finance, 57 (1), 1147-1170.

La Porta, R., F. Lopez-De-Silanes, and A. Shleifer. 1999. Corporate Ownership Around the World. The Journal of Finance, 54 (2).

La Porta, R. et al. 1998. Law and finance. Journal of Political Economy, 106 (3), 1113-1155.

La Porta, R. et al. 1997. Legal Determinants Of External Finance. Journal of Finance, 52 (3), 1131-1150.

Le, T. P. V., and T. B. N. Phan. 2017. Capital Structure And Firm Performance: Empirical Evidence From A Small Transition Country. Research in International Business and Finance, 42, 710-726.
Lee, Y., and S. Lee. 2014. Interaction Effects Between Ownership Concentration and Leverage on Firm Performance. Management Review: An International Journal, 9 (1), 70 106.

Lepore, L. et al. 2017. A Cross-Country Comparison of The Relationship Between Ownership Concentration And Firm Performance: Does Judicial System Efficiency Matter? Emerald Publishing Limited, 17 (2), 321-340.

Liu, H., and J. Wilson. 2009. The Profitability Of Banks In Japan: The Road To Recovery? Working Paper, Cass Business School.

Menicucci, E., and G. Paolucci. 2016. Determinants of Bank Profitability: Empirical Evidence From European Banking Sector. Journal of Financial Reporting and Accounting, 14 (1), 86-115.

Michaelas, N., F. Chittenden, and P. Putziouris. 1999. Financial policy and capital structure choice in UK SMEs: Empirical evidence from company panel data. Small Business Economics, 12, 113-130.

Musallam, S. R. M., H. Fauzi, and N. Nagu. 2018. Family, Institutional Investors Ownerships and Corporate Performance: The Case of Indonesia. Social Responsibility Journal.

Nachrowi, N. D., and H. Usman. 2006. Pendekatan Populer dan Praktis Ekonometrika untuk Analisis Ekonomi dan Keuangan. Jakarta: LPFE Universitas Indonesia.

Otoritas Jasa Keuangan. 2016. POJK tentangKepemilikanBank Umum. Diunduhtanggal 23 April 2019, https://www.ojk.go.id/id/regulasi/Pages/POJK-tentangKepemilikan-Bank-Umum.aspx

Otoritas Jasa Keuangan. 2018.Statistikperbankan Indonesia - September 2018. Diunduhtanggal 13 December2018, 
https://www.ojk.go.id/id/kanal/perbankan/data-dan-statistik/statistikperbankan-indonesia/Default.aspx

Ozili, P. K., and O. Uadiale. 2017. Ownership Concentration and Bank Profitability. Future Business Journal, 3, 159-171.

Putra, R. et al. 2019. Pengaruh Penerapan Tata Kelola Perusahaan Terhadap Profitabilitas Perbankan Di Indonesia. Studi Akuntansi dan Keuangan Indonesia, 2 (1), 98 - 123.

Rankin, M. et al. 2012. Contemporary Issues in Accounting. Singapore: John Wiley \& Sons Australia, Ltd.

Saidi, M. A., and B. Al-Shammari. 2015. Ownership Concentration, Ownership Composition, and the Performance of the Kuwaiti Listed NonFinancial Firms. International Journal of Commerce and Management, 25 (1), 108-132.

Sapienza, P. 2004. The Effects Of Government Ownership On Bank Lending. Journal of Financial Economics, 72 (2), 357-384.

Shleifer, A., and R. W. Vishny. 1997. A Survey of Corporate Governance. The Journal of Finance, 52 (2), 737783.

Shleifer, A., and R. W. Vishny. 1986. Large Shareholders and Corporate Control. Journal of Political Economy, 94 (31), 461-488.

Singh, D., H. Bathula, and S. S. Gaur. 2015. Ownership Concentration, Board Characteristics and Firm Performance, aContingency Framework. Management Decision, 53 (5), 911931.

Surifah. 2011. Kepemilikan Ultimat, Tingkat Risiko, Efisiensi dan Kinerja Industri. Perbankan Jurnal Siasat Bisnis, 15 (1), 37-53.

Utama, C.A., S. Utama, and F. Amarullah. 2017. Corporate Governance and Ownership Structure: Indonesia Evidence. Corporate Governance, 17 (2), 165-191.
Vo, X. V. 2017. Determinants of Capital Structure in Emerging Markets: Evidence from Vietnam. Research in International Business and Finance, 40, 105-113.

Wahba, H. 2008. Exploring The Moderating Effect Of Financial Performance On The Relationship Between Corporate Environmental Responsibility And Institutional Investors: Some Egyptian Evidence. Corporate Social Responsibility and Environmental Management, 15 (6), 361371.

Wardhani, R. 2007. Mekanisme Corporate Governance dalam Perusahaan yang MengalamiPermasalahanKeuangan. Jurnal Akuntansi dan Keuangan Indonesia, 4 (1), 95-114.

Yasser, Q. R., and A. A. Mamun. 2017. The Impact of Ownership Concentration Firm Performance: Evidence from an Emerging Market. Emerging Economy Studies, 3(1), 34-53. 